\title{
MENINGKATKAN KETERAMPILAN MENGUNGKAPKAN MONOLOG DESCRIPTIVE LISAN SEDERHANA YANG BERTERIMA SISWA KELAS VII-1 SMP NEGERI 5 TEBING TINGGI MENGGUNAKAN SISTIM ICARE
}

\author{
Delima Nuriana \\ Surel: delimanuriana2@gmail.com
}

\begin{abstract}
ABSTRAK
Penelitian Tindakan Kelas (PTK) ini merupakan suatu upaya untuk meningkatkan keterampilan mengungkapkan monolog Descriptive sederhana yang berterima (literary) bagi siswa Kelas VII-1 SMP Negeri 5 Tebing Tinggi. Hasil analisis data yang diperoleh dari hasil pengamatan dan angket siswa secara kualitatif dan secara kuantitaif diperoleh dari dokumen penilaian proses pembelajaran dan secara individu menunjukkan bahwa dengan menggunakan sistim ICARE, dapat meningkatkan keterampilan siswa mengungkapkan monolog descriptive lisan sederhana yang berterima terdapat peningkatan sebagai berikut: (1) meningkatnya keterampilan siswa mengungkapkan monolog descriptive sederhana, (2) meningkatnya kemampuan siswa didalam menggunakan bahasa Inggris lisan yang beterima dengan pengucapan yang relatif tepat, pada umumnya lancar dan menggunakan struktur kalimat yang tepat.
\end{abstract}

Kata Kunci: Monolog Descriptive Lisan, Sistim, ICARE

\section{PENDAHULUAN}

Kesulitan paling esensi yang penulis alami ketika membelajarkan siswa bahasa Inggris adalah bagaimana cara membelajarkan siswa untuk mengungkapkan bahasa tersebut secara lisan dan berterima. Pada umumnya siswa kurang mampu mengungkapkan bahasa lisan walaupun mereka telah mengalami pembelajaran dalam beberapa bahasan pada siklus lisan. Beberapa cara sudah penulis lakukan antara lain menambahkan waktu belajar khusus berbicara pada setiap hari sabtu melalui ekstrakurikuler conversation, siswa diberi tugas untuk belajar menggunakan bahasa lisan di sekolah atau di rumah secara berkelompok tetapi hasilnya masih kurang memuaskan karena masih $40 \%$ siswa belum terampil mengungkapkan bahasa Inggris secara lisan. Sedangkan $60 \%$ lainnya hanya mampu mengungkapkan dengan frekuensi rata-rata dua sampai dengan tiga kalimat saja dan dengan cara menghafalkan tulisan. Inilah fenomena kesulitan yang dialami oleh penulis di dalam membelajarkan siswa di sekolah.

Ketika penulis membaca buku Percikan Perjuangan Guru karya Profesor Surya yang menyatakan tentang perubahan paradigma guru pada abad ke 21, salah satu pernyataannya mampu menyadarkan penulis untuk berkreasi didalam membelajarkan siswa dengan cara yang kreatif, pernyataan tersebut tertulis sebagai berikut: "Guru akan lebih tampil tidak lagi sebagai pengajar (teacher) seperti fungsinya menonjol saat ini, melainkan sebagai: pelatih, konselor, manajer belajar, partisipan, pemimpin, dan 

pelajar", (Surya, 2003:334). Lebih mendalam dan rinci pada buku tersebut dijelaskan sebagai berikut: Pada kata pelatih dimaksudkan guru adalah seperti pelatih olah raga yang banyak membantu siswa dalam permainan (game of learning), membantu siswa menguasai alat belajar, memotivasi untuk kerja keras, bekerjasama dengan siswa yang lain. Sebagai konselor, guru akan menjadi sahabat siswa, teladan bagi pribadi yang mengundang rasa hormat dan keakraban. Struktur kelas, perlu ditata agar terjadi school within school dimana siswa belajar dalam kelompok-kelompok dalam bimbingan guru. Sebagai manajer, guru akan bertindak seperti manajer perusahaan, membimbing siswa belajar, mengambil prakarsa, ide-ide terbaik yang dimilikinya, namun disisi lain guru merupakan bagian dari siswa yang ikut belajar bersama mereka sebagai pelajar. Guru juga belajar dari teman seprofesinya melalui model team teaching. Pernyataan bijak di atas tentunya perlu diteladani dan dimaknai, artinya guru sebagai pengelolah pembelajaran harus selalu kreatif dan inovatif dalam menentukan stategi pembelajaran yang dapat membantu dan mempermudah siswa dalam belajar untuk mencapai kompetensi. Banyak strategi pembelajaran atau metoda yang ditawarkan agar siswa aktif dan kreatif yang seperti Quantumn Learning, Accelerated Learning, Cooperative Learning, Contextual Teaching and Learning dan sebagainya.
Setelah penulis membaca dan memahami beberapa strategi atau cara-cara bagaimana membelajarkan siswa yang aktif dan interaktif maka, penulis memilih salah satu strategi pembelajaran yang diperkirakan akan membuat siswa aktif dan interaktif mengungkapkan bahasa Inggris secara lisan yang berterima adalah sistem ICARE. Dengan sistem ICARE siswa akan menerapkan langsung komunikasi berdasarkan ide atau pengalaman belajar yang dimiliki, dengan demikian keterampilan siswa akan meningkat sebab seluruh siswa akan mempraktikkan bahasa lisan yang berterima selama proses pembelajaran. Di dalam standar kompetensi bahasa Inggris SMP memiliki beberapa wacana, salah satu wacana untuk Kelas VII adalah monolog descriptive sederhana. Berikut ini adalah salah satu standar kompetensi keterampilan berbicara yaitu: "Mengungkapkan makna dalam monolog pendek sangat sederhana dengan menggunakan ragam bahasa lisan secara akurat, lancar, dan berterima untuk berinteraksi dengan lingkungan terdekat dalam teks berbentuk descriptive dan procedure." (Standar isi, 2016; 4). Terdapat dua monolog dalam standar kompetensi pada keterampilan berbicara di atas, yaitu monolog descriptive dan procedure, wacana yang dipilih oleh penulis adalah monolog descriptive karena monolog descriptive struktur tatabahasa yang digunakan wacana ini lebih sederhana. Karena 
penelitian ini dilaksanakan pada semester ganjil maka dipilih bahasan monolog descriptive dengan menggunakan model pembelajaran ICARE.

Tujuan yang hendak dicapai dalam penelitian ini adalah sebagai berikut:

a. Meningkatkan keterampilan mengungkapkan monolog descriptive sederhana menggunakan bahasa Inggris lisan yang berterima siswa Kelas VII-1 SMP Negeri 5 Tebing Tinggi menggunakan sistem ICARE.

b. Meningkatnya kemampuan siswa didalam menggunakan bahasa Inggris lisan sederhana yang beterima dengan pengucapan yang relatif tepat, lancar dan menggunakan struktur kalimat yang tepat.

c. Meningkatkan rasa percaya diri siswa Kelas VII-1 SMP Negeri 5 Tebing Tinggi dalam mengungkapkan bahasa Inggris lisan sederhana yang berterima.

d. Meningkatkan keterampilan guru dalam membelajarkan siswa untuk mengungkapkan bahasa Inggris lisan sederhana yang berterima khususnya monolog descriptive sederhana.

e. Meningkatkan keterampilan guru di dalam membelajarkan siswa menggunakan sistem ICARE.

\section{METODE PENELITIAN}

Pendekatan yang dipergunakan dalam penelitian tindakan kelas ini adalah pendekatan kualitatif, sebab penelitian ini dilakukan karena terjadi permasalahan pembelajaran di kelas. Permasalahan ini ditindak lanjuti dengan cara menerapkan sebuah model pembelajaran yang diamati kemudian dianalisis dan direfleksi. Hasil revisi kemudian diterapkan kembali pada siklussiklus berikutnya.

Penelitian ini adalah penelitian tindakan kelas, model Stephen Kemmis dan Mc. Taggart (1998) yang diadopsi oleh Suranto (2000; 49). Model ini menggunakan sistem spiral refleksi diri yang dimulai dari rencana, tindakan, pengamatan, refleksi dan perencanaan kembali yang merupakan dasar untuk suatu ancang-ancang pemecahan masalah. Seperti yang diungkapkan oleh Mills $(200 ; 17)$ "Stephen Kemmis has created a well known representation of the action research spiral ...". Peneliti menggunakan model ini karena dianggap paling praktis dan aktual.

Penelitian tindakan kelas ini menggunakan tiga siklus, siklus I, siklus II dan siklus III, masingmasing siklus menggunakan empat tahapan, yaitu (1) menyusun rencana tindakan, (2) melaksanakan tindakan, (3) melakukan observasi, membuat analisis dilanjutkan dengan melakukan refleksi. Masing-masing siklus menggunakan waktu $2 \times 40$ menit. Dalam penelitian ini yang melakukan kegiatan pembelajaran adalah guru yang sekaligus berperan sebagai peneliti dan dibantu oleh dua orang selaku pengamat yang bertugas 
mengamati proses pembelajaran dan memberi masukan bagi guru atau peneliti untuk perbaikan tindakan berikutnya.

Untuk mengetahui hasil penelitian maka diperlukan data. Untuk mengumpulkan data dibutuhkan alat pengumpul data. Dalam penelitian ini dibutuhkan dua macam alat pengumpul data yaitu lembar observasi yang dipergunakan untuk mengamati aktivitas siswa dan guru, dan angket untuk melakukan klarifikasi antara hasil observasi oleh pengamat dengan responden selaku obyek yang diteliti dalam upaya meminimalkan kesenjangan hasil penelitian yang diperoleh dari pengolahan data. Teknik analisis data yang dilakukan adalah analisis kualitatif dan kuantitaif. Analisis kualitatif dipergunakan untuk mengelolah data hasil pengamatan selama proses pembelajaran, sedangkan analisis kuantatif dipergunakan untuk mengolah data hasil belajar untuk mengetahui peningkatan keterampilan siswa mengungkapkan monolog descriptive sederhana lisan yang berterima.

Lokasi penelitian tindakan kelas ini dilaksanakan di SMP Negeri 5 Tebing Tinggi subjek yang diteliti siswa Kelas VII-1. Kelas ini dipandang cukup representatif untuk penelitian tindakan kelas karena di kelas ini jumlah siswanya 37 (tiga puluh tujuh), sehingga dirasa cukup ideal. Menurut Kurikulum jumlah siswa setiap kelas idealnya tidak lebih dari empat puluh siswa. Sedangkan kemampuan siswa relatif cukup rata dengan berpedoman pada dokumen nilai hasil belajar yang dipergunakan siswa ketika mereka mendaftarkan diri pada Penerimaan Siswa Baru (PSB).

Penelitian ini dilaksanakan selama tiga bulan dari bulan April 2017 sampai dengan bulan Mei 2017.

\section{HASIL PENELITIAN DAN PEMBAHASAN}

Penelitian tindakan kelas ini berangkat dari kesulitan yang dialami guru atau penulis ketika membelajarkan siswa berbahasa Inggris lisan khususnya untuk mengungkapkan bahasa Inggris secara lisan dan berterima. Pada umumnya siswa Kelas VII-1 SMP Negeri 5 Tebing Tinggi kurang mampu mengungkapkan bahasa lisan walaupun mereka telah mengalami pembelajaran dalam beberapa bahasan pada siklus lisan. Masih terdapat $40 \%$ siswa belum terampil mengungkapkan bahasa Inggris secara lisan. Sedangkan 60\% lainnya mampu mengungkapkan dengan frekuensi rata-rata dua sampai dengan tiga kalimat saja dan dengan cara menghafalkan tulisan.Data ini diambil dari data empiris dokumen siswa Kelas VII tahun yang lalu dan data dokumen guru penilaian berbicara bahasa Inggris siswa pada semester gasal tahun ini. Untuk mengatasi permasalahan tersebut maka dilakukan penelitian tindakan kelas dan disusunlah suatu rencana pembelajaran yang menggunakan sistim ICARE yang dirancang dalam 
Delima Nuriana : Meningkatkan Keterampilan ...

tiga siklus pembelajaran

\section{SIKLUS I}

Jumlah siswa yang di Kelas VII1 adalah 37 (tiga puluh tujuh) siswa, yang tidak hadir sejumlah 3 orang sehingga yang hadir dalam penelitian ini sejumlah 34 (tiga puluh empat) siswa. Secara kuantitatif hasil belajar siswa tentang monolog descriptive lisan yang berterima menggunakan sistim ICARE dapat dipaparkan sebagai berikut:

a. Rata-rata skor pemahaman: 1266 : $34=37,2$. Artinya bila dikonversikan dengan kriteria penilaian monolog descriptive pada siklus I (Kriteria penilaian terlampir), maka siswa rata-rata mampu atau terampil mengungkapkan lebih dari 5 kalimat atau mendekati 6 kalimat. Sehingga pada pembelajaran yang akan datang perlu ditingkatkan jumlah kosa kata/kalimatnya.

b. Rata-rata skor pengucapan : 780 : $34=22,9$. Perolehan nilai pada pengucapan bila dikonversikan dengan kriteria penilaian monolog descriptive pada siklus I pada aspek pengucapan maka siswa cukup sering melakukan kesalahan pengucapan, untuk itu perlu perbaikan pada aktivitas pembelajaran yang akan datang.

\section{SIKLUS II}

Dari data pada siklus II Secara kuantitatif hasil belajar siswa tentang mengungkapkan monolog descriptive lisan sederhana dengan menggunakan sistim ICARE pada siklus II ini dapat digambarkan sebagai berikut:

a. Rata-rata skor pemahaman: 1056 : $27=39,1$. Rata-rata nilai ini bila dikonversikan dengan tabel kriteria penilaian monolog descriptive penilaian proses pembelajaran pada siklus II (Kriteria penilaian terlampir), maka rata-rata dari ke 27 siswa yang dibelajarkan telah terampil mengungkapkan 7 sampai dengan 10 kalimat. Hal ini menunjukkan bahwa hampir ke 27 siswa telah terampil mengungkapkan monolog descriptive yang ditargetkan dalam pembelajaran. Untuk mencapai Discourse Competence hasil penilaian dapat paparkan melalui kompetensi pendukungnya di bawah ini.

b. Rata-rata skor pengucapan : 424 : $27=15,7$. Perolehan rata-rata nilai pada pengucapan bila dikonversikan dengan kriteria penilaian monolog descriptive penilaian proses pada siklus II pada aspek pengucapan pada umumnya siswa kadang-kadang melakukan kesalahan pengucapan tetapi pengucapannya jelas.

c. Rata-rata skor kelancaran : 396 : $27=14,7$. Hasil penilaian kelancaran ini bila dikonversikan dengan kriteria penilaian monolog descriptive penilaian proses pembelajaran pada siklus II, menunjukkan 
bahwa siswa pada umumnya lancar didalam mengungkapkan monolog descriptive lisan.

d. Rata-rata skor struktur kalimat : $412: 27=15,3$. Data ini bila dikonversi dengan tabel kriteria penilaian monolog descriptive penilaian proses pembelajaran pada siklus II, menunjukkan bahwa pada umumnya siswa mampu menggunakan struktur kalimat yang dibelajarkan dalam monolog descriptive ini. Hanya beberapa siswa yang perlu dibelajarkan kembali pada siklus yang akan datang.

\section{SIKLUS III}

Pada siklus III ini, jumlah siswa di Kelas VII-1 yang hadir sejumlah 36 siswa, 1 siswa yang tidak hadir karena sakit. Secara kuantitatif hasil belajar siswa di siklus III ini dapat dipaparkan sebagai berikut:

a. Rata-rata skor pemahaman : $1384: 36=38,44$. Rata-rata nilai ini bila dikonversikan dengan kriteria penilaian mengungkapkan monolog descriptive lisan yang berterima pada penilaian proses pembelajaran pada siklus III, rata-rata nilai hasil belajar dari ke 36 siswa, menunjukkan telah terampil mengungkapkan 7 sampai dengan 10 kalimat.

b. Rata-rata skor pengucapan : 584 : $36=16,22$. Bila dikonversikan dengan kriteria penilaian mengungkapkan monolog descriptive lisan pada penilian proses, pada umumnya siswa kadang-kadang melakukan kesalahan pengucapan sampai dengan tidak pernah melakukan kesalahan dan pengucapannya jelas.

c. Rata-rata skor kelancaran : 540 : $36=15$. Hasil penilaian kelancaran ini bila dikonversikan dengan kriteria penilaian mengungkapkan monolog descriptive lisan pada penilaian proses pembelajaran pada siklus III, menunjukkan bahwa siswa pada umumnya lancar.

d. Rata-rata skor struktur kalimat : $604: 36=16,77$. Data ini bila dikonversi dengan kriteria penilaian mengungkapkan monolog descriptive lisan, menunjukkan bahwa pada umumnya siswa mampu menggunakan struktur kalimat yang dibelajarkan dalam monolog descriptive ini.

\section{Pembahasan}

Berdasarkan paparan di atas menunjukan bahwa aktivitas curah pendapat dapat meningkatkan keterampilan siswa di dalam menggunakan bahasa Inggris lisan yang berterima khususnya untuk mengungkapkan monolog descriptive. Terbukti dari analisis data secara kuantitatif menunjukkan bahwa nilai hasil belajar siswa pada umumnya diatas Standar Ketuntasan Belajar Minimal (SKBM) bahasa Inggris yaitu 70. Di samping itu terbentuk sikap percaya diri siswa, 
sikap bersosial, toleransi, dan minat belajar untuk aktualisasi diri.

Adapun

peningkatan gambaran keterampilan mengungkapkan monolog descriptive sederhana siswa Kelas VII-1 SMP Negeri 5 Tebing Tinggi secara lisan dapat dipaparkan sebagai berikut. (a) 100\% siswa telah mencapai Standar Ketuntasan Belajar Minimal (SKBM) yang ditunjukkan dari hasil belajar proses pembelajaran dengan kondisi beberapa siswa melakukan pembelajaran remidial dengan tutor sebaya. (b) Begitu juga pada penilaian Individu diperoleh data semua siswa yang berjumlah 37 mencapai SKBM dengan nilai yang variatif. (c) Secara kualitatif terlihat rasa percaya diri siswa meningkat dan siswa senang mendapatkan pembelajaran model ini. (d) Hasil analisis angket siswa juga menunjukkan bahwa dari 37 siswa memberi centangan pada kolom "ya" pada angket proses pembelajaran sesuai yang dialami siswa. Seluruh siswa juga menyatakan bahwa selama pembelajaran melalui aktivitas curah pendapat ini menyenangkan, membuat mereka percaya diri, siswa lebih sering mengungkapkan dengan bahasa mereka sendiri dan siswa merasa keterampilan mengungkapkan bahasa Inggris lisan mereka meningkat.

\section{SIMPULAN}

Pembelajaran bahasa Inggris mengungkapkan monolog descriptive lisan sederhana yang berterima menggunakan sistim ICARE, dilakukan melalui lima tahapan pembelajaran yaitu (1) Introduce (Perkenalkan), pada tahap ini guru memperkenalkan tujuan pembelajaran dan fungsi-fungsi sosial (lifeskills) yang terkait dalam proses pembelajaran. Guru memberikan permainan sederhana yang bertujuan untuk membangkitkan semangat siswa dalam belajar. (2) Tahap kedua, Connect (Hubungkan), guru berupaya untuk menghubungkan tujuan dan topik bahasan dengan sesuatu yang bermakna dalam kehidupan nyata. Pada pembelajaran monolog descriptive ini guru melakukan dengan cara bertanya langsung kepada siswa tentang sifat, warna, keadaan, bentuk dan sebagainya yang mendukung untuk mendiskripsikan sesuatu berkaitan dengan topik bahasan. (3) Pada tahap Apply (Terapkan), siswa mencoba untuk menerapan pengetahuannya seperti mengungkapkan bagianbagian wajah, bagian tubuh dan sebagainya melalui tanya jawab, atau bermain kuis. Pada aktivitas ini guru dapat memodelkan satu atau dua contoh wacana descriptive. (4) Tahap berikutnya adalah Reflect (Refleksikan), langkah ini guru membantu siswa menentukan hal-hal esensi yang diungkapkan seperti berupa clue-clue yang menjadi bahan catatan atau dokumen siswa. (5) Melatih siswa mendiskripsikan sesuatu dalam kelompok dan melakukan penilaian proses pembelajaran merupakan tahapan Extend (Perluaskan), dalam tahapan 
ini memungkinkan siswa mengelaborasi pengetahuannya dengan hal-hal yang bermakna dalam kehidupan, tahap ini sering memunculkan ide-ide kreatif siswa

Pembelajaran menggunakan sistem ICARE mengkondisikan siswa belajar berpendapat dan mengungkapkan pengetahuannya, mengaplikasikan, merefleksi dan memperluas pengalaman belajar mereka maka akan membentuk sikap percaya diri siswa karena siswa terlibat langsung mengaplikasikan pengetahuannya. Dengan model pembelajaran bahasa Inggris mengungkapkan monolog descriptive lisan menggunakan sistim ICARE ini siswa merasa senang, membuat mereka percaya diri, siswa mmapu menerapkan dengan bahasa mereka sendiri dan siswa merasa keterampilan mengungkapkan bahasa Inggris lisan mereka meningkat.

Untuk mengetahui keterampilan siswa dalam belajar maka dilakukan penilaian proses dan penilaian individu. Pembelajaran kompetensi linguistik seperti struktur kalimat, pengucapan, intonasi bisa dikaitkan atau disisipkan selama proses pembelajaran. Sedangkan penilaian proses pembelajaran ataupun penilaian individu mengacu pada bahasa Inggris yang berterima yaitu pencapaian Discourse Competence, dengan kompetensi pendukungnya Actional Competence, Linguistic Competence, Sociocultural Competence dan Strategic Competence sedangkan kompetensi tambahan yaitu Affective
Competence dipergunakan selama aktivitas pembelajaran.

\section{DAFTAR RUJUKAN}

Anwar, K. and Ananda, L. J. 2017. Pembuatan

"Science

Logbook" Melalui Scientific Approach Sebagai Upaya Meningkatkan Keterampilan Menulis Mahasiswa PGSD. School Education Journal PGSD FIP UNIMED, 6(2), pp.12-20.

Azies,FS \& Alwasilah CA. 1996. Penagajaran Bahasa Komunikatif Teori dan Praktik. Bandung: Remaja Rosdakarya Decentralized Based Education (DBE). 2016. Integrasi Kecakapan Hidup dalam Pembelajaran. USAID Indonesia.

Dirjendikdasmen. 2005. Landasan Filosofi Teoritis Pendidikan. Jakarta: Bahasa Inggris.

Mills, GE. 2000. Action Research A Guide For The Teacher Researcher. Ohio: Shoutern Oregon University.

Permen 22. 2016. Standar Isi Mata Pelajaran Bahasa Inggris. Jakarta.

Puskur. 2003. Standar Kompetensi Mata Pelajaran Bahasa Inggris SMP. Jakarta.

Suranto, Basowi, Sukidin. 2002. Manajemen Penelitian

Tindakan Kelas. Insan Cendekia.

Surya,M. 2003. Percikan Perjuangan Guru. Semarang: Aneka Ilmu. 